\title{
Family Businesses in Global Economy and Evaluating their Financial Health Using Bankruptcy Models
}

\author{
Maria Truchlikova ${ }^{1, *}$ \\ ${ }^{1}$ University of Economics in Bratislava, Faculty of Business Management, Dolnozemska cesta 1/b, 852 \\ 35 Bratislava, Slovakia
}

\begin{abstract}
Research background: Predicting and assessing financial health should be one of the most important activities for each business especially in context of turbulent business environment and global economy. The financial sustainability of family businesses has a direct and significant influence on the development and growth of the economy because they still represent the backbone of the economy and play an important role in national economies worldwide accounting.

Purpose of the article: We used in this article the financial distress and bankruptcy prediction models for assessing financial status of family businesses in agricultural sector. The aim of the paper is to compare models developed by using three different methods to identify a model with the highest predictive accuracy of financial distress and assess financial health. Methods: The data was obtained from Finstat database. For assessing the financial health of selected family businesses bankruptcy models were used: Chrastinova's CH-Index, Gurcik's G-Index (defined for Slovak agricultural enterprises) and Altman Z-score.

Findings \& Value added: This article summarizes existing models and compares results of assessing financial health of family businesses using three different models.
\end{abstract}

Keywords: family businesses; financial health; bankruptcy model; Altman Z-score.

JEL Classification: $M 21 ; M 29 ; G 39$

\section{Introduction}

Financial health of company is one of the most important issues of company especially in current turbulent business environment and in process of globalization, when failure or financial distress of one entity adversely affects the financial performance of all other entities. During the last decades, the issue of the prediction of financial distress of the companies has been a very interesting topic, as it is very important mainly for the managers of the companies, but also for the employees, credit and business partners of the company, but

\footnotetext{
*Corresponding author: maria.truchlikova@euba.sk
} 
overall for all other interested stakeholders (Durica and Frnda and Svabova, 2021; Hosaka 2019; Paule-Vianez and Gutierrez-Fernandez and Coca-Perez, 2020).

The financial distress of business entities is closely connected with unpleasant consequences, and these are the main motivation factors for managers or financial analysts to search for the methods that can predict possible financial problems or bankruptcy in advance (Gregova et al., 2020; Valaskova et al., 2020). That's the reason why predicting corporate bankruptcy should have place in risk management. Family businesses have to face to the same problems as non-family businesses, but it is possible, that characteristics of family businesses could be a possible reason for family business risk aversion and the choice of capital structure. One of the most discussed topics in the literature is whether a family business has a better performance than non-family business, so that they do not experience financial distress. Several different methods or models were created to identify risk of bankruptcy or financial distress of company. The accuracy of prediction models is reduced significantly if the model is used in another industry, another time or in a different business environment compared to the data used to derive the model (Karpac and Bartosova, 2020). The aim of this paper is to evaluate the financial health of agricultural family businesses using selected methods.

\section{Financial health prediction models}

Predicting and assessing financial health is not new area. An effective warning system is crucial for the prediction of the financial situation in corporate governance (Pavlicko et al., 2021). The earliest researchers were Beaver and Altman and their models are one of the most cited in literature. Their models are based on calculation of financial ratios from financial statements. These ratios can be used to predict financial distress of company or bankruptcy. Altman considered simultaneous impact of several indicators on the financial condition of the company by combining them into a single measure (Z-score). He used the technique of the multivariate linear discriminant analysis to achieve this purpose (Prusak, 2018). Later, some researchers created models based on logit and probit analysis - Ohlson O-Score was derived from a study of more than 2000 companies (Rahman et al., 2021) (used set of nine accounting ratios) or Zmijewski (three-variable distress prediction model) (Ashraf et al., 2019). In conditions Slovak republic, several models have been developed. Chrastinova (1998) and Gurcik (2002) belonged to the first researchers who developed models for the Slovak conditions - they were based on using linear multivariate discriminant analysis (Prusak, 2018). Chrastinova model CH - index was created especially for agriculture companies and analysed 1,123 enterprises from agricultural sector. The second model developed by Gurcik G-indes allows differentiate the agriculture companies into two groupsprosperous and non-prosperous (Gurcik, 2002; Bielikova, 2014). Construction of this model is based on Altman Z-score, Bonity index and $\mathrm{CH}$-index. The sample of 60 agriculture companies were divided to prosperous and non-prosperous (Bielikova, 2014). The construction of these two models respected both the general industry-specific character of agricultural production and the competitive vulnerability of the Slovak agricultural sector. Each of these prediction models is constructed by linear discriminant analysis as a linear combination of five suitably selected financial indicators serving as predictors of corporate financial status (Boda and Uradnicek, 2019). These models have been developed for the companies in agriculture and they belong to the most discussed models (Prusak, 2018; Boda and Uradnicek, 2019; Vavrek et al., 2021; Durica et al., 2019). Valaskova et al. (2020) verified the predictive ability of the bankruptcy models formed in conditions of the Slovak economy in the sector of agriculture and confirm that the highest predictive ability of the bankruptcy prediction models is achieved provided that they are used in the same economic conditions and industrial sector in which they were primarily developed. The agriculture can 
be characterized by high volatility of companies' financial results and instability of economic development due to changes in the market, production, prices or weather conditions (Bielikova, 2014).

Family businesses have to face the same problems as the non-family businesses. But there are some specific characteristics in context of financial performance and risk of financial distress. Many authors (Anderson and Reeb, 2003) have revealed that family businesses perform better than others. The reason is the involvement family members in management of the business and risk aversion of family members. Moreover, families may be carrying a reputation, which plays a significant role in both political and economic markets thanks to their performance, or connections (Burkart et al., 2003). These relationships help to the family businesses to get external finance without difficulty. That is the reason why, family firms tend to have better access to the capital market (Murro et al., 2019). Because family businesses are considered backbone of economy, recent studies are focusing to analyse financial performance of family businesses and difference between family and non-family businesses in context of leverage and debt financing. It therefore takes into consideration the existence of any significant differences between the leverage and risk choices of family and non-family firms (Ntoung, 2020). Some studies state that economies, capital structure and leverage policies of family businesses are not much different than the non-family firms (Haider, 2021).

\section{Methodology and data}

The data was obtained from Finstat database. This database contains financial data about all subjects with a registered ID in the Slovak Republic. We analysed financial situation of family businesses operating in the agricultural sector (NACE A-Agriculture, forestry, and fishing). We analysed a sample of 161 family businesses in Slovakia. Financial statements from 2019 were analysed. The analysis carried out was based on models predicting financial distress. Methods such as linear discriminant analysis and logistic regression belong to classical statistical methods applied in prediction of corporate default risk. For assessing the financial health of selected family businesses 3 models predicting financial distress were used: model of Gurcik (G-index), model of Chrastinova (CH-index) and Altman's Z-score.

Model of Chrastinova (CH-index) is based on Altman's Z-score model and Beerman's index, and has form:

Table 1. CH-index indicators

\begin{tabular}{|l|l|l|}
\hline $\begin{array}{l}\text { Prediction model and } \\
\text { formula }\end{array}$ & Variables & $\begin{array}{l}\text { The classification of the } \\
\text { resulting values }\end{array}$ \\
\hline $\mathbf{C H}$-index & $\begin{array}{l}\mathrm{X} 1=\mathrm{EAT} / \text { total capital, } \\
\mathrm{X} 2=\mathrm{EAT} / \text { revenues } \\
\mathrm{X} 3=\mathrm{Cash} \text { flow / debt } \\
\mathrm{X} 4=\mathrm{debt} / \text { revenues } \\
\mathrm{X} 5=\mathrm{debt} / \text { total capital } \\
\mathrm{healthy} \\
\text { situation of the company; } \\
-5<\mathrm{CH} \leq 2.5 \text { neutral } \\
0,21 \mathrm{X} 3-0,10 \mathrm{X} 4-0,07 \mathrm{X} 5\end{array}$ & $\begin{array}{l}\text { zone of unallocated } \\
\text { results } \\
\mathrm{CH} \leq-5 \text { unhealthy } \\
\text { financial situation of the } \\
\text { company }\end{array}$ \\
\hline
\end{tabular}

Source: own processing according to Chrastinova (1998)

Model of Gurcik (G-index) is based on Altman's Z-score, Beerman's index and Ch-index 
And its calculation is shown in Table 2.

Table 2. G-index indicators

\begin{tabular}{|c|c|c|}
\hline $\begin{array}{l}\text { Prediction model and } \\
\text { formula }\end{array}$ & Variables & $\begin{array}{l}\text { The classification of the } \\
\text { resulting values }\end{array}$ \\
\hline $\begin{array}{l}\text { G-index } \\
\mathrm{G}=3,412 \mathrm{X} 1+2,226 \mathrm{X} 2+ \\
3,277 \mathrm{X} 3+3,149 \mathrm{X} 4- \\
2,063 \mathrm{X} 5\end{array}$ & $\begin{array}{l}\mathrm{X} 1=\text { retained earnings } \\
\text { liabilities } \\
\mathrm{X} 2=\mathrm{EBT} / \text { liabilities } \\
\mathrm{X} 3=\mathrm{EBT} / \text { revenues } \\
\mathrm{X} 4=\text { Cash flow } / \text { liabilities } \\
\mathrm{X} 5=\text { inventory } / \text { revenues }\end{array}$ & $\begin{array}{l}\mathrm{G}>1.8 \text { is for healthy } \\
\text { financial situation of the } \\
\text { company } \\
-0.6<\mathrm{G} \leq 1.8 \text { neutral } \\
\text { zone of unallocated } \\
\text { results and } \\
\mathrm{G} \leq-0.6 \text { for unhealthy } \\
\text { financial situation of the } \\
\text { company }\end{array}$ \\
\hline
\end{tabular}

Source: own processing according to Gurcik (2002)

Table 3. Altman Z-score indicators

\begin{tabular}{|c|c|c|}
\hline $\begin{array}{lll}\begin{array}{l}\text { Prediction model } \\
\text { formula }\end{array} & \text { and } \\
\end{array}$ & Variables & $\begin{array}{l}\text { The classification of the } \\
\text { resulting values }\end{array}$ \\
\hline $\begin{array}{l}\text { Altman Z-score } \\
\begin{array}{l}\mathrm{Z}=0,717 \mathrm{X} 1+0,847 \mathrm{X} 2+ \\
3,107 \mathrm{X} 3+0,420 \mathrm{X} 4+ \\
0,998 \mathrm{X} 5\end{array}\end{array}$ & $\begin{array}{l}\mathrm{X} 1=\text { working capital/total } \\
\text { assets } \\
\mathrm{X} 2=\text { retained earnings/total } \\
\text { assets } \\
\mathrm{X} 3=\text { earnings before interest } \\
\text { and taxes/ } \\
\text { total assets } \\
\mathrm{X} 4=\text { equity/liabilities } \\
\mathrm{X} 5=\text { sales/total assets }\end{array}$ & $\begin{array}{l}Z^{\prime}>2.9 \text { "Safe" Zone } \\
1.23<Z^{\prime}<2.9 \text { "Grey" } \\
\text { Zone } \\
Z^{\prime}<1.23 \text { "Distress" } \\
\text { Zone }\end{array}$ \\
\hline
\end{tabular}

Source: own processing according to Altman (1968)

The measurement of predictive performance is often based on the analysis of data in a confusion matrix:

- $\quad$ True Positive (TP): An item is predicted as faulty, and it is faulty

- $\quad$ False Positive (FP): An item is predicted as faulty, and it is not faulty

- $\quad$ True Negative (TN): An item is predicted as not faulty, and it is not faulty

- $\quad$ False Negative (FN): An item is predicted as not faulty, and it is faulty

We selected the business entities into two categories -prosperous and non-prosperous. The firm in the state of bankruptcy is regulated in accordance with the Section 3 of the Act No. 7/2005 Coll. on Bankruptcy and Restructuring as amended. The firm in bankruptcy is insolvent or the value of its equity is lower than total debts. The firm in a danger of financial failure is identified directly in the Commercial Code, Section 67a (2) - its equity to debt ratio is lower that 4:100 (the value of ratio that is valid for 2016), or 6:100 (for 2017), or 8:100 (since 2018). In terms of financial analysis, this ratio is a balance indicator of the degree of financial independence. There are also other criteria that indicate financial crisis - for example equity to debt ratio is lower than 0.04 , current ratio lower than 1 , earnings after taxes (EBIT) is negative. 
We also calculated:

- Sensitivity, what is the proportion of actual positives which are correctly identified as such: TP / (TP + FN)

- Specificity, what is the proportion of negatives which are correctly identified as such: $\mathrm{TN} /(\mathrm{FP}+\mathrm{TN})$

- Accuracy: $(\mathrm{TP}+\mathrm{TN}) /(\mathrm{TP}+\mathrm{FP}+\mathrm{FN}+\mathrm{TN})$

- Empirical Error I evaluates the number of true positives which were classified as true negatives: FN/TP + FN

- Empirical Error II shows how many of true negatives were classified false positives: $\mathrm{FP} / \mathrm{FP}+\mathrm{TN}$

Table 4. Confusion matrix

\begin{tabular}{|c|c|c|c|}
\hline \multicolumn{4}{|c|}{ Current category } \\
\hline \multirow{3}{*}{$\begin{array}{c}\text { Predicted } \\
\text { category }\end{array}$} & $\mathrm{T}$ & True positives (TP) & False positives (FP) \\
\cline { 2 - 4 } & $\mathrm{F}$ & False negatives (FN) & $\begin{array}{c}\text { True negatives } \\
(\mathrm{TN})\end{array}$ \\
\hline
\end{tabular}

Source: own processing

\section{Results}

Of the total number of 161 companies, we are 130 companies as prosperous, with favorable financial health, but we identified 31 non-prosperous enterprises. During the verification process of the prediction models, we applied selected predictions models, the model of Chrastinova, Gurcik, developed in the conditions of the Slovak economy and one of the most cited model - Altman model. Table 5 records the results of the calculations.

Table 5. Prosperous and non - prosperous companies

\begin{tabular}{|c|c|c|c|c|c|c|c|c|}
\hline \multicolumn{3}{|c|}{ CH-index } & \multicolumn{3}{c|}{ G-index } & \multicolumn{3}{c|}{ Altman Z-score } \\
\hline & $\begin{array}{c}\text { Non- } \\
\text { prosp. }\end{array}$ & Prosp. & & $\begin{array}{c}\text { Non- } \\
\text { prosp. }\end{array}$ & Prosp. & & $\begin{array}{c}\text { Non- } \\
\text { prosp. }\end{array}$ & Prosp. \\
\hline $\begin{array}{c}\text { Non- } \\
\text { prosp. }\end{array}$ & 0 & 0 & $\begin{array}{c}\text { Non- } \\
\text { prosper. }\end{array}$ & 13 & 20 & $\begin{array}{c}\text { Non- } \\
\text { prosper. }\end{array}$ & 27 & 48 \\
\hline Prosper. & 31 & 130 & Prosper. & 18 & 110 & Prosper. & 4 & 82 \\
\hline
\end{tabular}

Source: own processing

From the table 6 it is clear that the $\mathrm{CH}$-index correctly identified 130 prosperous enterprises $(80,75 \%)$, but none non-prosperous, despite the fact that there are 31 such companies. In the case of Gurcik's model, it was correct identified 110 prosperous enterprises $(85,94 \%)$. To complete the comparison, Altman's model correctly identified 82 prosperous enterprises $(95,34 \%)$.

Table 6. Model's Comparison

\begin{tabular}{|c|c|c|c|}
\hline Model & CH-index & G-index & $\begin{array}{c}\text { Altman- Z } \\
\text { score }\end{array}$ \\
\hline Sensitivity & $80,75 \%$ & $85,94 \%$ & $95,34 \%$ \\
\hline Specificity & $0 \%$ & $39,39 \%$ & $36 \%$ \\
\hline Accuracy & $80,75 \%$ & $76,40 \%$ & $67,70 \%$ \\
\hline
\end{tabular}




\begin{tabular}{|c|c|c|c|}
\hline Type I Err. & $0 \%$ & $15,38 \%$ & $36,92 \%$ \\
\hline Type II Err. & $100 \%$ & $58,06 \%$ & $12,90 \%$ \\
\hline AUC & $50 \%$ & $63 \%$ & $75 \%$ \\
\hline
\end{tabular}

Source: own processing

Based on results shown in table 6 , we see that almost $75 \%$ of Slovak agricultural family businesess is correctly classified using Altman model. The results of calculation and comparison of models are graphically logged using ROC curves, which show the individual models distinguish between prosperous and non-prosperous financial situation of the company.
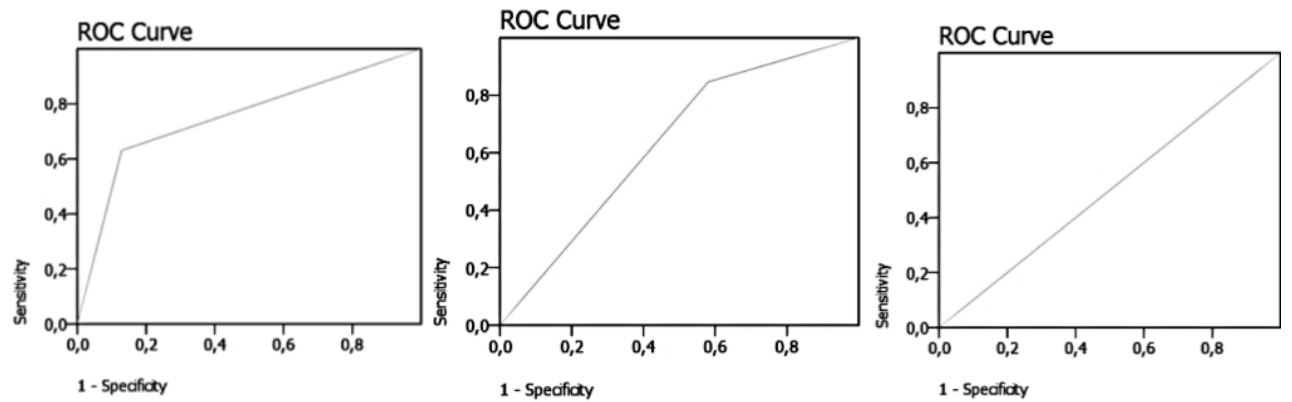

Figure 1. ROC curve for Altman, Gurcik and Chrastinova model

Source: own processing

The AUC parameter reaches out $75 \%$ for the Altman model application, and thus it can be demonstrated that this prediction model has a good classification ability.

\section{Conclusion}

Many researchers have discussed the specific features of family businesses in context of financial performance. Family businesses tend to be more concervative and less risky, most family firms use less debt financing and try to reinvest profit. Using debt financing can lead to the financial problems and cause financiel distress or bankruptcy. It is important for each businesses (family or non-family) to evaluate the financial situation using diffenrent methods and models.

The methods of forecasting the financial distress of the business can classificate the businesses into two groups - prosperous and non-prosperous using different financial ratios. The aim of this paper was to evaluate the financial health of agricultural family businesses using selected methods. One of them is multidimensional discriminant analysis, which was used as well for the only Slovak prediction models Chrastinova and Gurcik, which were constructed for agricultural businesses. The third model was Altman model (Z-score). For this contribution, 161 entities from agriculture sector were analysed. However, based on the results obtained, we can say that even though Gurcik model and Chrastinova model were developed in the conditions of Slovak agriculture, the best classification and predictive ability reaches the Altman model.

We also processed the ROC curve analysis, from which the resulting AUC value under the curve, was a clear indication that the chosen predictive model was able to clearly predict the financial health of the enterprise in the selected sector of Slovakia (in case of Altman model, classification capability in the area is achieving $75 \%$ ). 
Our research has some limitations. In Slovak republic is still missing legislatively definition of family business and database of family businesses. Another limitation is that data for processing were obtained only on based on a single source. The research focusses only on family businesses in agriculture and on evaluating their financial health. For the future investigation should be made a comparison between family and non-family businesses in selected industry/sector.

\section{Acknowledgements}

This paper is the output of the scientific grant VEGA no. 1/0240/20 „Financial Aspects of Sustainable Business - Enterprise Succession Solution for Small and Medium-sized Enterprises " $(50 \%)$ and the internal grant project of the University of Economics in Bratislava (Faculty of Business Management) No. I-21-109-11-00 called "Research of Family Businesses in Context of Sustainable Development " $(50 \%)$.

\section{References}

1. Altman, E. I. (1968). Financial ratios, discriminant analysis and the prediction of corporate bankruptcy. Journal of Finance, 589-609.

2. Anderson, R., Reeb, D. (2003). Founding-family ownership, corporate diversification, and firm leverage. The Journal of Law \& Economics, 46(2), 653-684.

3. Ashraf S, G. S., Félix, E., Serrasqueiro, Z. (2019). Do Traditional Financial Distress Prediction Models Predict the Early Warning Signs of Financial Distress? Journal of Risk and Financial Management. 12(2), 55.

4. Bielikova, T., Banyiova, T., Piterkova, A. (2014). Prediction Techniques of Agriculture Enterprises Failure. Procedia Economics and Finance, 12, 48-56.

5. Boda, M., Uradnicek, V. (2019). Predicting Financial Distress of Slovak Agricultural Enterprises. Ekonomický časopis, 67(4), 426-452.

6. Burkart, M., Panunzi, F., Shleifer, A. (2003). Family firms. The Journal of Finance, 58(5), 2167-2201.

7. Durica, M., Svabova, L., Frnda, J. (2021). Financial distress prediction in Slovakia: An application of the cart algorithm. Journal of International Studies, 14(1), 201-215.

8. Durica, M., Podhorska, I., Durana, P. (2019). Business failure prediciton using cartbased model: A case of Slovak companies. Ekonomicko-manazerske spektrum, 13(1), 51-61.

9. Gregova, E., Valaskova, K., Adamko, P. Tumpach, M., Jaros, J. (2020). Predicting Financial Distress of Slovak Enterprises: Comparison of Selected Traditional and Learning Algorithms Methods. Sustainability, 12(10), 3954.

10. Gurcik, L. (2002). G-index - the financial situation prognosis method of agricultural enterprises. Agricultural Economics, 48, 373-378.

11. Haider J., Qayyum A., Zainudin Z. (2021). Are Family Firms More Levered? An Analysis of Family and Non-Family Firms, SAGE Open, 11(2).

12. Hosaka, T. (2019). Bankruptcy prediction using imaged financial ratios and convolutional neural networks. Expert Systems with Application, 117, 287-299.

13. Chrastinova, Z. (1998). Methods of economic creditworthiness evaluation and prediction of financial situation of agricultural holdings. Bratislava: VUEPP. 
14. Karpac, D., \& Bartosova, V. (2020). The verification of prediction and classification ability of selected Slovak prediction models and their emplacement in forecasts of financial health of a company in aspect of globalization. In SHS Web of Conferences (Vol. 74, p. 06010). EDP Sciences.

15. Murro, P., Peruzzib, V. (2019). Family firms and access to credit: Is family ownership beneficial? Journal of Banking \& Finance, 101, 173-187.

16. Ntoung, L.A.T.; Santos de Oliveira, H.M.; Sousa, B.M.F.d.; Pimentel, L.M.; Bastos, S.A.M.C. (2020). Are Family Firms Financially Healthier Than Non-Family Firm? Journal of Risk Financial Management. 13(5).

17. Paule-Vianez, J., Gutierrez-Fernández, M., Coca-Perez, J.L. (2020). Prediction of financial distress in the Spanish banking system: An application using artificial neural networks. Applied Economic Analysis, 28, 69-87.

18. Pavlicko, M.; Durica, M.; Mazanec, J. (2021). Ensemble Model of the Financial Distress Prediction in Visegrad Group Countries. Mathematics, 9(16), 1886.

19. Prusak, B. (2018). Review of Research into Enterprise Bankruptcy Prediction in Selected Central and Eastern European Countries. International Journal of Financial Studies, $6(3), 60$.

20. Rahman, M., Li Sa, Ch., Masud, A. K. (2021). Predicting Firms' Financial Distress: An Empirical Analysis Using the F-Score Model. Journal of Risk and Financial Management, 14(5), 199.

21. Valaskova. K., Durana, P., Adamko, P., Jaros, J. (2020). Financial Compass for Slovak Enterprises: Modeling Economic Stability of Agricultural Entities. Journal of Risk and Financial Management. 13(5),92.

22. Vavrek R., Kravcakova, Z., Kotulic, R. (2021). Evaluating the Financial Health of Agricultural Enterprises in the Conditions of the Slovak Republic Using Bankruptcy Models. Agriculture, 11(3), 242. 